悪性転化した上顎エナメル上皮腫の 1 例

\author{
山口万枝・小山貴司・松下文彦・橋本賢二
}

\title{
A case of ameloblastoma of maxilla with malignant transformation
}

\author{
Kazue Yamaguchi $\cdot$ Takashi Koyama $\cdot$ Fumihiko Matsushita $\cdot$ Kenji Hashimoto
}

\begin{abstract}
Malignant ameloblastoma is a very rare odontogenic carcinoma of the jaws. We describe a case of ameloblastoma of the maxilla in which malignant transformation from ameloblastoma not detected on biopsy was found on histological examination of surgical specimens.

A 77-year-old Japanese woman presented with a swelling of the palate. The swelling measured $3 \mathrm{~cm}$ in diameter and was associated with spontaneous pain and an ulcer. The histological diagnosis of a biopsy specimen was ameloblastoma, with no evidence of malignant features. There was no adenopathy of the regional lymph nodes. The tumor was removed by partial resection of the maxilla. The patient received $60 \mathrm{~Gy}$ of ${ }^{60} \mathrm{Co}$ postoperatively because malignant transformation was found on histological examination of surgical specimens.

Microscopic examination showed malignant transformation of ameloblastoma. The tumor cells consisted of ameloblast-like cells in the benign area, but showed pleomorphism, atypism, squamous metaplasia, and keratin pearl formation in the malignant area. There was transition between the two areas. These findings suggest that the malignant ameloblastoma developed from a preexisting ameloblastoma.
\end{abstract}

Key words: malignant ameloblastoma（悪性エナメル上皮腫）, malignant odontogenic tumor (悪性歯原性腫 湯), ameloblastoma (エナメル上皮腫), malignant transformation（悪性転化）

緒言

悪性エナメル上皮腫は, 顎骨に発生するきわめてまれな 歯原性悪性腫場である. 診断は困難であり, 多くの分類 1,2$)$ が報告されてきた. 従来は, 転移の認められたエナメル上 皮腫を悪性エナメル上皮腫と診断していたが, 1992年の WHO による歯原性悪性腫瘍の分類 ${ }^{3)}$ により，転移の有無 に関わらず, 組織学的に悪性像を呈する腫瘍を悪性エナメ ル上皮腫と診断するようになった.

今回われわれは, 生検でエナメル上皮腫と診断され, 切 除物病理組織所見で悪性像が認められた, 口蓋に発生した まれな悪性エナメル上皮腫の 1 例を経験した. 本症例にお いて, 組織学的観察を行い, エナメル上皮腫からの悪性転

浜松医科大学医学部歯科口腔外科学講座

(主任 : 橋本賢二教授)

Department of Dentistry and Oral and Maxillofacial

Surgery, Hamamatsu University School of Medicine

(Chief: Prof. Kenji Hashimoto)

受付日 : 平成10年12月18日
化を示唆する興味ある知見を得たので, 症例の概要ととも に報告する。

症例

患 者 : 77歳, 女性.

主 訴 : 口蓋の腫脹.

初診: 1994年 7 月回.

現病歴 : 約 4 週前より, 口蓋に有痛性膨隆を認めたため, 近歯科医より紹介され, 当科初診となった。

既往歴 : 狭心症 (64歳時).

生活歴 : 喫煙歴, 飲酒歴なし.

家族歴 : 特記事項なし.

現 症: 全身状態良好, 顔貌に左右差なし. 両側頸部リ ンパ節腫脹なし. 口腔内所見は, 右硬口蓋に直径 $3 \mathrm{~cm}$ の, 自発痛を伴い, 中央に潰瘍形成を伴う弾性硬の膨隆を認め た (写真 1 ). パントモX 線写真, デンタルX 線写真で 3 根 尖部の X 線透過像および右上顎洞底の骨破壊像が確認さ 


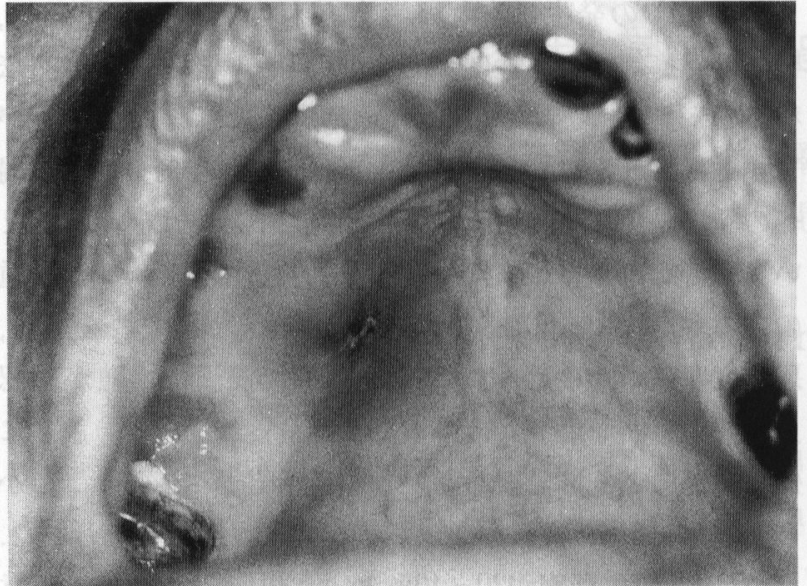

写真 1 初診時口腔内写真

右硬口蓋に直径 $3 \mathrm{~cm}$ の潰瘍形成を伴う弾性硬の膨隆を 認めた。

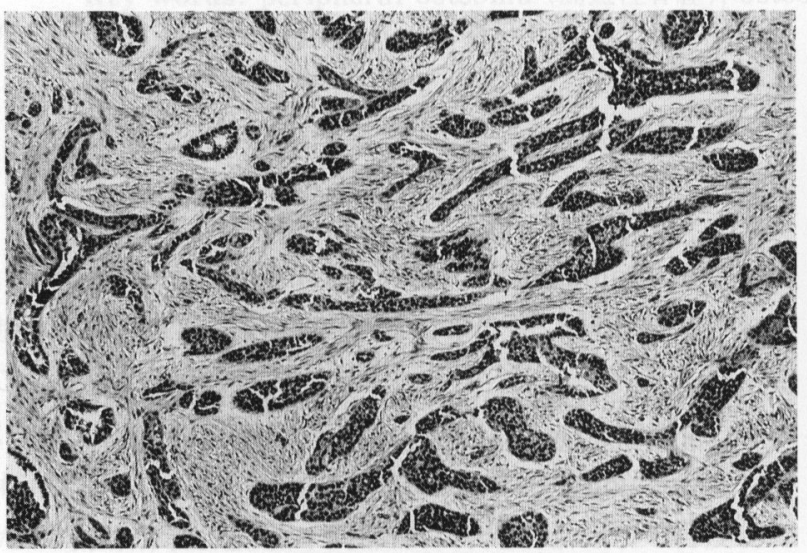

写真 3 切除物光顕像 (HE 染色, 原倍率 $\times 100)$ 腫瘍細胞は胞巣を形成し浸潤増殖していた。

れた.さらに, CT (写真 2 ), MRIによる精査を行ったとこ ろ, 長径約 $3 \mathrm{~cm}$ の腫瘍が右上顎洞底部に認められ, 右上顎 洞下壁および内側壁の浸潤性骨破壊像が確認された.

臨床診断 : 右上顎腫瘍.

処置および経過 : 画像所見から悪性腫瘍も疑い潰瘍部の 生検を施行したところ，エナメル上皮腫と診断された．両 側頸部リンパ節腫脹や遠隔転移が認められなかったため, 1994年12月ロ日, 全身麻酔下に, 上顎腫瘍切除術を施行し た. 術後の病理組織学的診断は, 悪性エナメル上皮腫で あった.さらに, 上顎骨および上顎洞粘膜への腫瘍浸潤が 認められ，切除範囲が不十分であると考えられたため, 1995年 2 月曰日から 3 月ロ日, ${ }^{60} \mathrm{Co} 60 \mathrm{~Gy}$ の外照射を施行した。術 後, 上顎に義歯を装着し摂食障害は改善された. 現在まで,

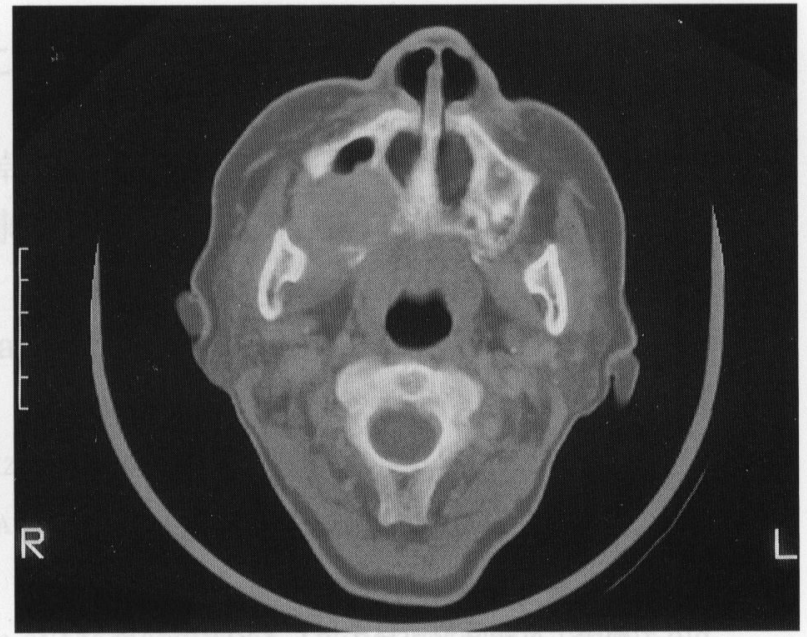

写真 2 CT 写真 上顎洞底の骨が破壊されていた。

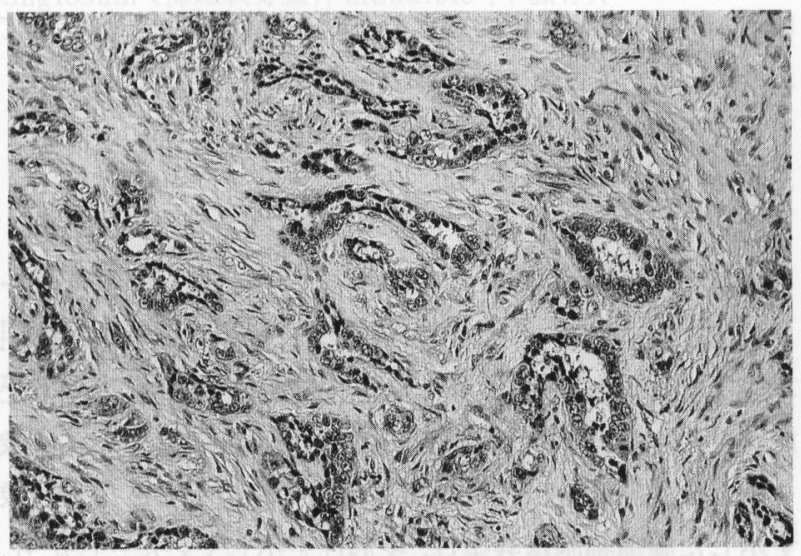

写真 4 切除物光顕像 $(\mathrm{HE}$ 染色, 原倍率 $\times 100)$ 腫大した腫湯細胞では, 異型核が認められた.

再発, 転移なく経過良好である。

病理組織学的所見

1 ) 生検光顕所見

腫瘍細胞の外形および核は紡錘形で，エナメル芽細胞に 類似し, 線維性結合組織内で柵状配列を呈し増殖していた. 細胞異型性は軽度で, 明らかな悪性所見は認められなかっ た。

\section{2 ) 切除物光顕所見}

腫瘍細胞はエナメル芽細胞に類似した紡錘形で，胞巣を 形成し浸潤増殖していた (写真 3 ).さらに同一標本上の腫 大した腫瘍細胞では, $\mathrm{N} / \mathrm{C}$ の増加, 核の多形性と異型性, クロマチンの凝集, 異常な核分裂像が観察された（写真 4 ). 腫瘍細胞の浸潤増殖が顕著な部位では, 細胞の極性は消失 


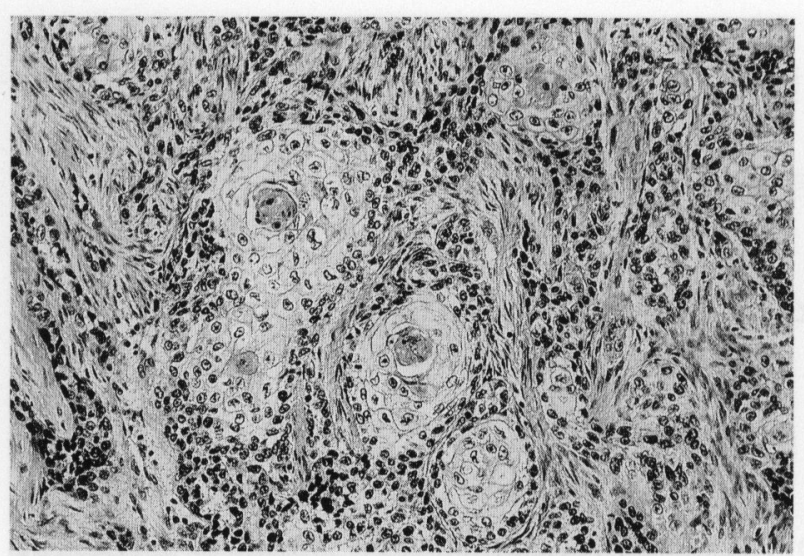

写真 5 切除物光顕像 $(\mathrm{HE}$ 染色, 原倍率 $\times 100)$ 扁平上皮癌類似所見を呈していた.

し，癌真珠の形成など扁平上皮癌類似所見を呈していた (写真 5 ). 切除標本上で腫瘍の 7 割程度が悪性像を呈して おり,一部では骨への浸潤像が観察された。

病理組織診断 : 悪性エナメル上皮腫.

\section{考察}

悪性エナメル上皮腫では, エナメル上皮腫から悪性エナ メル上皮腫へ悪性化する所見が観察されるとの報告がある ${ }^{1)}$. 本症例では, 光顕的にエナメル上皮腫様腫瘍細胞が扁平上 皮化生, 癌真珠の形成等を伴って悪性化しており，良性像 を示した腫瘍細胞はエナメル芽細胞の性格を有し, 悪性像 を示した腫瘍細胞は異型性, 多形性を示していた。しかも， この良性から悪性への変化が連続的に観察された. 本腫瘍 の起源は, エナメル上皮腫の悪性化あるいは原発的に悪性 としての発生が考えられている ${ }^{1,3)}$. 本症例では, 前述の ような病理組織像が観察されたことより, 良性腫瘍である エナメル上皮腫が悪性化し, 悪性エナメル上皮腫となった と考えられた.

歯原性悪性腫瘍の診断は困難なことが多い. 特に, 顎骨 内原発上皮性腫瘍では, 腫瘍胞巣周辺部に, 歯原性上皮に 類似した柵状配列がしばしば観察される ${ }^{4}$ ). 本症例のよう に, 生検でエナメル上皮腫のような良性病変の診断がなさ れても, 画像所見で不規則な骨破壊を示す部位では病理組 織検査で浸潤増殖を示す悪性所見を認める場合があるの で, 精査する必要がある.

悪性エナメル上皮腫は, 上䫟より下顎に好発し ${ }^{2)}$, 上顎 では前歯部に発生したという報告 ${ }^{1)}$ はあるが, 本症例のよ
うに口蓋での発生はまれと考えられた ${ }^{2)}$. 本腫瘍は, 個々の腫瘍細胞の悪性度が高く ${ }^{5)}$, 局所再発やリンパ節転 移, 肺転移 2,6$)$ を起こしやすい. 治療法は外科的切除術が まず選択される 7,8$)$ が, 頸部リンパ節転移症例や切除断端 への腫瘍浸潤が認められる場合は, 放射線照射を行ったと いう報告がある 6 ，8). 本症例では，(1)悪性エナメル上皮腫 の中でも，原発巣が扁平上皮癌に類似した異型性を呈し， 悪性度が高いと考えられた ${ }^{6)}$ ，(2)骨への浸潤性増殖が確認 され切除範囲が不十分であったと考えられた ${ }^{2)}$, (3)さらに 残存腫湯による再発率が高いという報告がある9)ことか ら, 上顎に発生した扁平上皮癌に準じ術後照射を施行した. しかし，5 年生存率が $30-40 \%$ という報告 ${ }^{2}$ 〕あり，注意 深い経過観察が必要と考えられた。

結語

上顎に発生したまれな悪性エナメル上皮腫の 1 例を報告 した. 切除標本の病理組織学的所見より, 本症例はエナメ ル上皮腫より発生した悪性エナメル上皮腫であると考えら れた。

\section{引用 文 献}

1) Slootweg, P.J., and Müller, H.: Malignant ameloblastoma or ameloblastic carcinoma. Oral Surg 57: 168-176 1984.

2) Corio, R.L., Goldblatt, L.I., et al.: Ameloblastic carcinoma: A clinicopathologic study and assessment of eight cases. Oral Surg 64: 570-576 1987.

3) Kramer, I.R.H., Pindborg, J.J., et al.: Histological typing of odontogenic tumours. Geneva, World Health Organization, 1992, p24-26.

4）下条嘉秀: 口腔腫場の超微形態学的研究 II. 悪性工 ナメル上皮腫と口腔扁平上皮癌との比較. 臨床電顕 誌 29: 23-31 1996.

5) Müller, S., DeRose, P.B., et al.: DNA ploidy of ameloblastoma and ameloblastic carcinoma of the jaws. Arch Pathol Lab Med 117: 1126-1131 1993.

6) Laughlin, E.H.: Metastasizing ameloblastoma. Cancer 64: 776-780 1989.

7) Gandy, S.G., Keller, E.E., et al.: Ameloblastic carcinoma: Report of two cases. J Oral Maxillofac Surg 50: 1097-1102 1992.

8) Simko, E.J., Brannon, R.B., et al.: Ameloblastic carcinoma of the mandible. Head \& Neck 20: 654-659 1998.

9) Sehdev, M.K., Huvos, A.G., et al.: Ameloblastoma of maxilla and mandible. Cancer 33: 324333, 1974. 